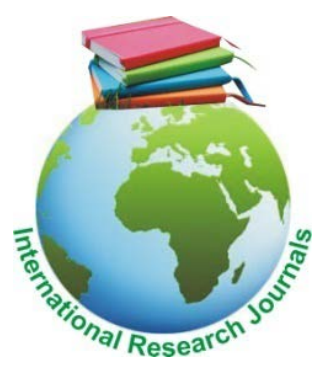

African Journal of Food Science and Technology (ISSN: 2141-5455) Vol. 9(2) pp. 19-24, July, 2018

DOI: http:/dx.doi.org/10.14303/ajfst.2018.230

Available online https://www.interesjournals.org/food-science-technology.html

Copyright (c)2018 International Research Journals

Full Length Research Paper

\title{
Pre harvest and post-harvest assessment of geohelminth and protozoan parasites contamination of vegetables in Ibadan, Southwest, Nigeria
}

\author{
Falohun O.O*, Adejinmi J.O., Odenibi B.S. and Obebe O.O.
}

Department of Veterinary Parasitology, University of Ibadan, Oyo State, Nigeria, farry4real2k@yahoo.com

\begin{abstract}
Consumption of fresh vegetables is one of the major routes of transmission of intestinal parasites of public health importance which have been incriminated as one of the main causes of foodborne outbreaks. In an attempt to bridge the knowledge gap associated with the pre-harvest and post-harvest parasitic contamination of vegetables in Nigeria, this study was conducted to assess geohelminths and protozoa contamination of vegetables in farms and markets in Ibadan, southwest, Nigeria. Vegetable samples were screened using simple floatation and sedimentation methods for identification of geohelminths ova, larva and protozoan oocysts. Of the total 200 vegetable samples collected, $70(35 \%)$ were positive for geohelminth and protozoan parasites. The results show that the highest level of contamination was detected in African spinach 20 (35.1\%), followed by White jute $15(45.5 \%)$, Waterleaf $14(51.9 \%)$, Quill grass $12(24.5 \%)$, Garden eggplant leaf $4(57.1 \%)$, while the least number of contaminated samples was detected in Pepper $1(\%)$. However, Fluted pumpkin leaves and English Spinach had no parasitic contamination. Waterleaf $3(11.11 \%)$, African spinach $2(3.5 \%)$, Quill grass $2(4.1 \%)$ and White jute $2(6.1 \%)$ had mixed helminths and protozoa infections. Of the total intestinal parasites observed, Strongyloides stercoralis had the highest prevalence 67 (33.5\%), followed by Entamoeba coli 27 (13.5\%), Ascaris spp. 24 (12\%), Trichuris spp. 10 (5\%), Filiariform 9 (4.5\%), Dicrocoelium spp. 9 (4.5\%), Oesophagostomum dentatum 7 (3.5\%), Fasciola spp 7 (3.5\%), Entamoeba histolytica $6(3 \%)$ while Eimeria spp $6(3 \%)$ had the lowest prevalence. Most farmers $44(80 \%)$ used stream and waste water as their source of irrigation while $11(20 \%)$ of the farmers used well and stream. The relatively high rate of parasitic contamination observed in this study might be due to poor hygienic and sanitary handling of vegetables, poor transportation, packaging of vegetables and contaminated water used for irrigation and washing of vegetables in farms and markets. There is therefore a need for education of farmers and market women on proper handling and hygienic management of vegetables to safe guard the health of the populace.
\end{abstract}

Keywords: Intestinal parasites, vegetables, farms, markets, Nigeria.

\section{INTRODUCTION}

Vegetables contain valuable food components which have been strongly associated with maintenance of good health and prevention of diseases (Hanif et al., 2006; Keatinge et al., 2010). Vegetables can become contaminated with enteric parasitic pathogens throughout the process of planting to consumption and pparasites from contaminated vegetables can pose potential health risk to humans; therefore food safety irrespective of the specific food item should be of utmost concern to everybody involved in the food chain (Amoah et al., 2006; Kays, 2011). Vegetables are sometimes eaten raw or parboiled to retain the natural taste and preserve heat labile nutrients (Said, 2012; Slifko et al.,
2009). This practice favours the likelihood of food-borne parasitic infections in humans (Sunil et al., 2014). The level of contamination depends on numerous factors which include the use of untreated waste water and water supplies contaminated with sewage for irrigation (Simoes et al., 2011; Beuchat, 2002; Amoah et al., 2006). The contamination of vegetables with geohelminths and food borne protozoa can occur at any time during the food chain, this can be pre-harvest: occurring on farms which include soil, faeces (human and animal origin) and water (irrigation, cleaning) (Halablab et al., 2011; Amoah et al., 2009). Also, contamination may be post-harvest, occurring during transportation and in market places which include rinsing and sprinkling with contaminated water (Mensah et al., 2002; Alade et al., 2013; Olyaei \& 
Hajivandi, 2013). Over the years, very few studies have been conducted on parasitic contamination of vegetables in Nigeria (Obetta et al., 2011; Elom et al., 2012; Alade et al., 2013). All these studies focused on vegetables from open markets (during post-harvest periods). However, none has considered the assessment of pre and postharvest parasitic contamination of vegetables from farms and markets in Nigeria. This present study was therefore conducted to assess parasitic contamination on vegetables from selected farms and markets in Ibadan. Information obtained from this assessment may help in the development of preventive and control strategies that will raise people's awareness and safeguard the health and welfare of the community. This information is also required to assist the local health authorities to be able to take the proper actions to improve the quality of vegetables being sold to the populace for consumption.

\section{MATERIALS AND METHODOLOGY}

\section{Study Design and Sample Collection}

200 vegetables were sampled from three major farms from which 55 farmers practice olericulture and from five main commercial markets from six Local Government areas in Ibadan, Southwestern, Nigeria. Eight common vegetables eaten by the people in the area were used for this study. The vegetables used are Tomatoes (Lycopersicum sativus), Water leaf (Talinium triangulare), Quill grass (Celosia argenta), African spinach (Amaranthus hybridus) White jute (Corchorus olitorius), Fluted pumpkin leaf (Telfaria occidentalis) Garden eggplant leaf (Solanium macrocarpon) and Pepper (Capsicum Chinese). These were chosen because they are the major vegetables eaten by the residents of Ibadan. A total of 1100 vegetables strands pooled into 20 strands per sample making 55 samples were collected from farms while a total of 2900 vegetables strands pooled into 20 strands per sample making up to 145 samples were bought from sellers in each of the open markets selected for the study making a total of 200 samples of vegetables.

\section{Parasitological Analysis}

\section{Floatation Method}

$100-200 \mathrm{~g}$ samples of each vegetable were washed in $0.85 \%$ saline solution in a plastic container for $10-24$ $\mathrm{h}$ for the removal of parasitic ova, larva or cysts. The suspension was strained through a sterile sieve to remove debris and then centrifuged at $4000 \mathrm{rpm}$ for $5 \mathrm{~min}$ and the supernatant discarded into the disinfectant jar. The sediment obtained was re-suspended in sodium chloride floatation fluid and re-centrifuged. The floatation fluid was added to fill to the brim and a cover slip was superimposed on it. The cover slip was lifted, placed on the glass slide and examined under microscope using X100 and
X400 objectives (Nyarango et al., 2008). The parasite eggs was identified on the basis of their morphological characteristics shape and size, and compared with standard eggs on charts using The Bench Aid for the Diagnosis of Intestinal Parasites.

\section{Sedimentation method}

100-200 g samples of vegetable was washed in 0.85\% saline solution in a $15 \mathrm{ml}$ test tube for $5 \mathrm{~h}$ and then centrifuged at $3500 \mathrm{rpm}$ for 5 min (Damen et al., 2008). A drop of the sediment was mixed with two drops of lugol's iodine solution. The process was systematically repeated until the mixture in each test tube was exhausted and examined under a light microscope using X100 and X400 objectives (Garcia, 2007). Ova, oocysts and larvae of parasites found under the light microscope were identified as previously described by (Downes \& Ito, 2001).

\section{Statistical Analysis}

Data was entered into a Microsoft excel spread sheet and analyzed using descriptive analysis. Graphs and tables were used to calculate distribution frequency of geohelminths with regards to vegetable species, locations sampled and method of irrigation.

\section{RESULT}

Of the total 200 vegetable samples examined, 70 (35\%) were positive for geohelminths and protozoan parasite. The parasites detected were Strongyloides stercoralis, Ascaris spp., Trichuris spp., Oesophagostomum dentatum, Fasciola spp., Dicrocoelium spp., Entamoeba histolytica, Entamoeba coli and Eimeria spp. Strongyloides stercoralis has the highest prevalence 67 (33.5\%), followed by Entamoeba coli 27 (13.5\%), Ascaris spp. 24 (12\%), Trichuris spp. 10 (5\%), Filiariform 9 (4.5\%), Dicrocoelium spp. 9 (4.5\%), Oesophagostomum dentatum 7 (3.5\%), Fasciola spp 7 (3.5\%), Entamoeba histolytica 6 (3\%) and Eimeria spp. 6 (3\%) had the lowest prevalence (Figures1 and 2). Out of the six local Government area investigated, Lagelu has the highest level of parasitic contamination 13 (100\%) of the total 13 vegetables collected with Strongyloides stercoralis being the most prevalent $8(61.5 \%)$. This is followed by Ibadan southwest 23 (57.5\%), Ibadan north 22 (32.4\%), Akinyele local government 11 (29\%), while Ido local government has the lowest level of parasitic contamination 3 (8.8\%) (Table 1). Of the six markets investigated, Oja Oba market has the highest level of parasitic contamination with 23 (57.5\%), followed by Oojo market 10 (37.04\%), Bodija market 13 (35.14\%), Oje market 2 (28.6\%) and Eleyele market $3(8.82 \%)$ (Table 1$)$. The highest level of contaminated was detected in African spinach 20 (35.1\%), followed by White jute 15 (45.5\%), Waterleaf 14 (51.9\%), Quill grass 12 (24.5\%), Garden eggplant leaves 4 (57.1\%), while the least contamination was detected in Pepper 1 (50 


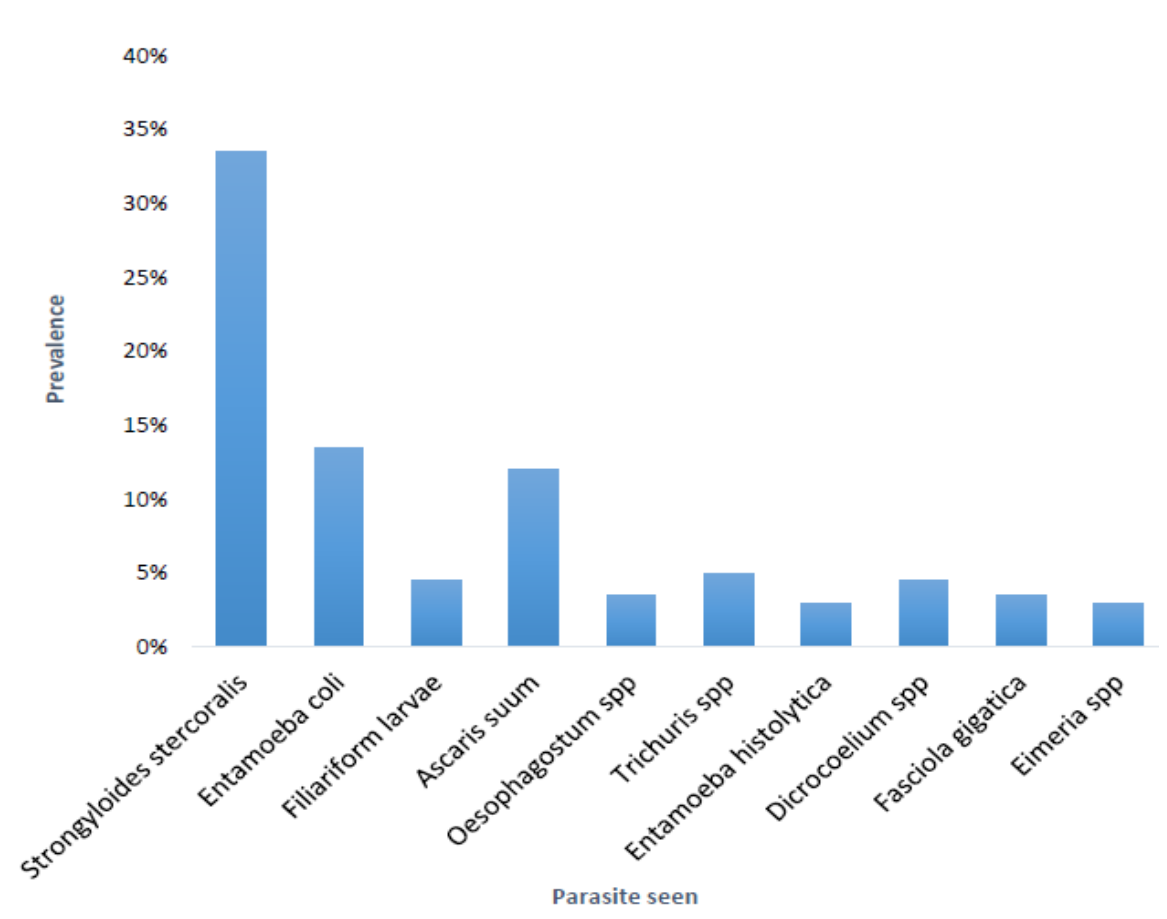

Figure 1: Percentage Prevalence of Parasites found in farms and markets.
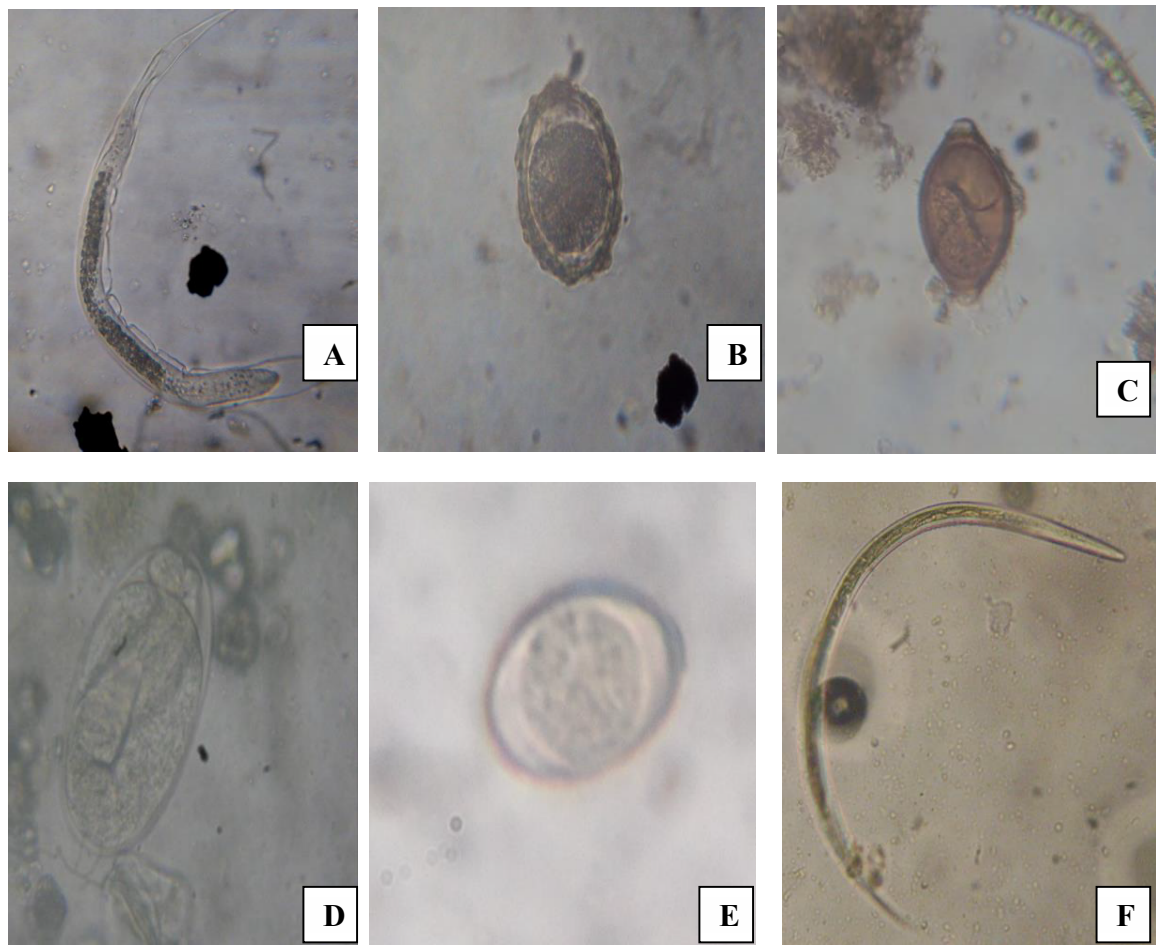

Figure 2: showing some of the geohelminths egg and larva with protozoa oocyst detected in different vegetable species collected in Ibadan metropolis.

A: Oesophagostomum dentatum larvae, B: Ascaris spp, C: Trichuris spp.

D: Strongyloides stercoralis egg E: Eimeria spp. F: Strongyloides stercoralis larva (first stage) 
$\%)$, however, fluted pumpkin leaves and English spinach had no parasitic contamination. The result showed that Waterleaf 3 (11.1\%), African spinach 2 (3.5\%), Quill grass $2(4.1 \%)$ and White jute $2(6.1 \%)$ had mixed helminths and protozoa infections (Table 3). Out of all the farmers interviewed, 11 (20\%) used animal faeces and chemical as fertilizers, 31 (56.4\%) used animal feaces only as their fertilizer source while 13 (23.6\%) used chemical as their source of fertilizer. Most farmers 44 (80\%) used stream and waste water as their source of irrigation while 11 (20\%) of the farmers used well and stream (Tables 1-3).

\section{DISCUSSION}

Consumption of fresh vegetables is an essential route of transmission of intestinal parasites of public health importance which have been incriminated as one of the main causes of foodborne outbreaks (Daryani et al., 2008; Pires et al., 2012). From this present study, the overall prevalence of geohelminths and protozoan parasites observed is similar to the findings of other authors in Vietnam (Uga et al., 2009) and in Nigeria (Damen et al., 2007). However, it is higher than that reported in Iran (Daryani et al., 2008), in Pakistan (ul-Haq et al., 2014) and in Yemen (Alsubaie et al., 2014). It is however lower than the observation of (Alade et al., 2013) in Nigeria and (Hajjami et al., 2013) in Morocco. The high level of contamination of African spinach observed in this present study might be due to their broad leaves and their development near ground level which provide large contact area with contaminated water and soil (ulHaq et al., 2014). African spinach and other green leafy vegetables have uneven surfaces that make parasitic eggs, cysts and larvae attached to their surface more easily when washed with contaminated water either in the farm or in market (Damen et al., 2007). Strongyloides spp, Entamoeba coli, Ascaris suum and Trichuris spp. were among the intestinal parasites of public health importance detected in vegetables from farms and markets, as this is similar to the observations of previous authors in Ethopia (Gimaye \& Fedaku, 2014), in Pakistan (Anwar \& Mckenry, 2012) and in Nigeria (Uneke, 2004; Baker, 2007). Strongyloides stercoralis is a common cause of morbidity and mortality particularly in developing countries, as this parasite has the ability to auto-infect the host which makes it a significant public health problem (Roxby et al., 2009). The risk of acquiring strongyloidiasis

Table 1: Distribution of geohelminths and protozoa in vegetables sampled from different Local Government areas in Ibadan metropolis.

\begin{tabular}{|l|l|l|l|l|}
\hline \multirow{2}{*}{ LGA } & Number & No. (\%) & Parasite observed \\
\cline { 3 - 5 } & Examined & Positive & Helminths & Protozoa \\
\hline Ibadan North & 68 & $22(32.4)$ & Strongyloides stercoralis, Filariform larvae, Ascaris spp., Fasciola spp. & Entamoeba coli, Eimeria spp. \\
\hline Akinyele & 38 & $11(28.5)$ & Strongyloides stercoralis, Dicrocoelium spp. Ascaris spp. & - \\
\hline Ido & 34 & $3(8.82)$ & Strongyloides stercoralis. & - \\
\hline Lagelu & 13 & $13(100)$ & Strongyloides stercoralis, Filiariform larvae. & Entamoeba coli, \\
\hline Ibadan southwest & 40 & $23(57.5)$ & $\begin{array}{l}\text { Ascaris spp., Oesophagotum dentatum, Dicrocoelum } \text { spp., Trichuris spp., } \\
\text { Strongyloides stercoralis. }\end{array}$ & $\begin{array}{l}\text { Entamoeba coli, Entamoeba } \\
\text { histolytica, Eimeria spp. }\end{array}$ \\
\hline lbadan northeast & 7 & $2(28.6)$ & Strongyloides stercoralis. & - \\
\hline
\end{tabular}

Table 2: Prevalence of geohelminths and protozoa in vegetables from sampled markets in Ibadan metropolis.

\begin{tabular}{|l|c|c|}
\hline Market & No.(\%) examined & No. (\%) positive \\
\hline Bodija & $37(18.5)$ & $13(35.14)$ \\
\hline Oja oba & $40(20)$ & $23(57.5)$ \\
\hline Oojo & $27(13.5)$ & $10(37.04)$ \\
\hline Oje & $7(3.5)$ & $2(28.6)$ \\
\hline Eleyele & $34(17)$ & $3(8.82)$ \\
\hline
\end{tabular}

Table 3: Prevalence of geohelminths and protozoa in different vegetables species collected in Ibadan metropolis

\begin{tabular}{|c|c|c|c|c|c|}
\hline \multirow{2}{*}{ Vegetables } & \multirow{2}{*}{ Common name } & \multirow{2}{*}{$\begin{array}{l}\text { No. }(\%) \\
\text { examined }\end{array}$} & \multirow{2}{*}{$\begin{array}{l}\text { No. }(\%) \\
\text { positive }\end{array}$} & \multicolumn{2}{|l|}{ Parasite observed } \\
\hline & & & & Helminths & Protozoa \\
\hline Amaranthus hybridus & African spinach & $57(28.5)$ & $20(35.1)$ & $\begin{array}{c}\text { Strongyloides stercoralis, Trichuris spp., Oesophagotum } \\
\text { dentatum, Dicrocoelum spp., Filiarifom larvae. }\end{array}$ & $\begin{array}{l}\text { Entamoeba coli, Entamoeba } \\
\text { histolytica. }\end{array}$ \\
\hline Corchorus olitorius & Jute & $33(16.5)$ & $15(45.5)$ & $\begin{array}{l}\text { Strongyloides stercoralis, Trichuris spp, Fasciola spp., } \\
\text { Ascaris spp. }\end{array}$ & $\begin{array}{l}\text { Entamoeba coli, Entamoeba } \\
\text { histolytica, Eimeria spp. }\end{array}$ \\
\hline Celosia argentia & Quill grass & $49(24.5)$ & $12(24.5)$ & $\begin{array}{l}\text { Strongyloides stercoralis, Trichuris spp, Fasciola spp., } \\
\text { Ascaris spp. }\end{array}$ & Entamoeba coli, Eimeria spp. \\
\hline Solanium macrocarpon & Garden eggleaf & $7(3.5)$ & $4(57.1)$ & Strongyloides stercoralis & Entamoeba coli \\
\hline Talinum triangulare & waterleaf & $27(13.5)$ & $14(51.9)$ & $\begin{array}{l}\text { Strongyloides stercoralis, Dicrocoelum spp Ascaris spp., } \\
\text { Oesophagotum spp. }\end{array}$ & Eimeria spp. \\
\hline Solanum lycopersicum & Tomato & $10(5)$ & $3(30)$ & Strongyloides stercoralis, Ascaris spp. & _ \\
\hline Capsicum chinese & Pepper & $2(1)$ & $1(50)$ & Ascaris spp. & _ \\
\hline Basella alba & English spinach & $1(0.5)$ & $0(0)$ & _- & __ \\
\hline
\end{tabular}


is higher in rural areas, among people who work with soil and among lower socio-economic groups (Vadlamudi et al., 2006; Viney \& Lok, 2007). It is important to note that the presence of these parasites may be due to lack of modern toilet facilities, poor sewage disposal and inadequate public health enlightenment which make people defecate indiscriminately in the environment resulting in pollution of water and soil (Tsado et al., 2013). The species of Ascaris detected in this study may probably be Ascaris suum, this is due to the usage of pig faeces as a major fertilizer as stated by one of the farmers. Ascaris suum has been known to be a zoonotic parasite causing viscera larva migrant in humans (Baker, 2007; Dutto \& Petrosillo, 2013). The threat of infection with intestinal parasites in the community is increased because these contaminated vegetables are sometimes eaten raw or parboiled to retain the natural taste and preserve heat labile nutrients (Slifko et al., 2009). These findings may have an essential implication for food safety and emphasize the importance of raw vegetables in threatening public health by transmission of zoonotic parasites to humans in Ibadan. A greater percentage of the farms investigated in this study applied untreated organic manure (animal faeces) for the cultivation of their vegetables. Choice of fertilizer was dependent mainly on cost and availability, as the expensive nature of inorganic fertilizers makes farmers opt for untreated organic fertilizer. However, the use of untreated organic fertilizer pre-dispose vegetables to feacal helminthes contamination as humans can consequently be infected when these vegetables are consumed undercooked or raw (Daryani et al., 2008). Although vegetable farmers using wastewater as their source of irrigation in this study are aware of the fact that the use of wastewater can pose a major hazard to their health, however, inability to have access to potable water for irrigation, which is also expensive has restrained them to using wastewater. (Obuobie et al., 2006) noted that farmers practicing olericulture lack better options hence end up using wastewater sources for irrigation which in most cases are not paid for and are readily available. There is therefore a need for education of farmers and market women on proper handling and hygienic management of vegetables to safe guard the health of the populace.

\section{REFERENCES}

Alade GO, Alade TO, Adewuyi IK (2013) Prevalence of intestinal parasites in vegetables sold in Ilorin, Nigeria. American-Eurasian. J. Agric. \& Environ. Sci. 13(9): 1275-1282.

Alsubaie, ASR, AL-Mekhlafi AMK, AL-Shibani LAN, AL-Eryani SMA, Azazy AAA (2014). Hygienic Assessment of Pathogenic Contamination in Raw Vegetables in Local Markets: an Implication for Public Health. Int. Res. J. Microbiol. 5(2)16-21.
Amoah P, Drechsel P, Abaidoo RC, Abraham EM (2009). Improving food hygiene in Africa where vegetables are irrigated with polluted water. Regional Sanitation and Hygiene Symposium. Accra.

Amoah P, Drechsel P, Abaidoo RC, Klutse A (2007) Effectiveness of common and improved sanitary washing methods in selected cities of West Africa for the reduction of coliform bacteria and helminth eggs on vegetables. Trop. Med. Int. Health. 12(2): 40-50.

Anwar SA, Mckenry MV (2012). Incidence and Population Density of plant parasitic Nematodes infecting vegetable crops and associated yield losses in Punjab, Pakistan. Pakistan J. Zool. 44(2): 327-333.

Baker DG (2007). Flying parasites of laboratory animals. In: baker ( $2^{\text {nd }}$ eds), Wiley-Blackwell, American college of laboratory animal medicine, Louisiana.

Beuchat CR (2002). Ecological factors Influencing survival and growth of human pathogens on raw fruits and vegetables. Microbes Infect. 4(4): 413-423.

Damen JG, Banwat EB, Egah DZ, Allanana JA (2007). Parasitic contamination of vegetables in Jos, Nigeria. Ann. Afr. Med. 6(3): 115-118.

Daryani A, Ettehad GH, Sharif M, Ghorbani, L, Ziaei. (2008). Prevalence of intestinal parasites invegetables consumed in Ardabil, Iran. Food Contr. 19(8): 790-794.

Downes FP, Ito K (2001). Compendium of methods for the microbiological examination of foods In: ( $4^{\text {th }}$ Eds) Washington, DC, American Public Health Association.

Dutto M, Petrosillo N (2013). Hybrid Ascaris suum/ lumbricoides (Ascarididae) infestation in a pig handler-A rare case of zoonotic Ascariasis. Cent. Eur. J. Public. Health 21(4): 224-226.

Elom O M, Ukpai AE, Nworie A, Akpotomi IO (2012). Prevalence of geohelminths on edible fruits and vegetables cultivated in rural villages of Ebonyi State, South East Nigeria. Am. J. Food. Nutr. 2(3): 58-64.

Garcia LS (2007). Macroscopic and microscopic examination of faecal specimens. In: L. Garcia, and L. S. Garcia ( $5^{\text {th }}$ Eds.) Diagnostic Medical Parasitology. Washington, DC: American Society of Microbiology.

Gimaye B, Fedaku G (2014). Parasitic contamination of vegetables irrigated with Awash River in selected farms, Eastern Showa, Ethiopia. J. Parasitol. Vector Biol. 6(7): 103-109.

Hajjami K, Ennaji MM, Amdiouni H, Fouad S, Cohen N (2013). Parasistic contamination on fresh vegetable consumed in Casablanca City (Morocco) and Risk for Consumer. Int. J. Sci.Technol. 2(7).

Halablab MA, Sheet IH, Holail MM (2011). Microbiological quality of raw vegetables grown in 
Bekea Valley, Lebanon. Am. J. Food. Technol. 6(2): 129139 ?

Hanif R, Iqbal Z, Iqbal M,Hanif S, Rasheed M (2006). Use of vegetables as nutritional food: Role in human health. J. Agric. Bio. Sci. 1(1): 18-22.

Kays SJ (2011). Cultivated Vegetables of the World: A Multi-lingual Onomasticon. The Netherlands: Wageningen Academic Publishers.

Keatinge JDH, Waliyar F, Jamnadas RH, Moustafa A (2010). Re-Learning old lessons for the future of food: By bread alone no longer - diversifying diets with fruit and vegetables. Crop Sci. 50(1): 51-62.

Mensah P, Yeboah-Manu D, Owusu-Darko K, Abiordey A (2002). Street Foods in Accra, Ghana: How safe are they? Bull. World Health Organization 80(7): 546-554.

Nyarango RM, Aloo PA, Kabiru EW, Nyanchongi BO (2008). The risk of pathogenic intestinal parasite infections in Kisii Municipality, Kenya. BMC Public Health 8: 237

Obetta SE, Nwakonobi TU, Adikwu OA (2011). Microbial effects on selected stored fruits and vegetables under ambient conditions in Makurdi, Benue State, Nigeria. Res. J. Appl. Sci. Eng. Technol. 3(5): 393-398.

Obuobie E, Keraita B, Danso G, Amoah P, Cofie OO, Raschid-sally L, Drechsel P (2006). Irrigated urban vegetable production in Ghana: Characteristics, benefits and risks. IWMI-RAUF-CPWF.

Olyaei A, Hajivandi L (2013). Parasitological contamination of markets and farms in vegetables consumed in Southern Iran. Glob. Vet. 10(3): 327-331.

Pires SM, Vieira AR, Perez E, Fo L Wong D, Hald T (2012). Attributing human foodborne illness to food sources and water in Latin America and the Caribbean using data from outbreak investigations. Int $\mathrm{J}$ Food Microbiol. 152(3):129-138.
Roxby AC, Gottlieb GS, Limaye AP (2009). Strongyloidiasis in transplant patients. Clin. Infect. Dis. 49(9): 1411-1423.

Said D (2012). Detection of parasites in commonly consumed vegetables. Alex. J. Med. 48(4): 345-352.

Simoes M, Plsani B, Margues EG (2001). Hygienic sanitary conditions of vegetables and irrigation water from kitchen gardens in the municipality of Campinas, SP. Braz. J. Microbiol. 32(4): 331-333.

Slifko TR, Smith HV, Rose JB (2009). Emerging parasites zoonoses associated with water and food. Int. J. Parasitol. 30(12-13): 1379-1393.

Sunil B, Thomas D, Latha C, Shameen H(2014). Assessment of parasitic contamination of raw vegetables in Mannuthy, Kerala State, India. Vet. World 7(4): 253-256.

Tsado EK, Adesina OA, Oyeleke SB (2013). A survey on the bacterial load of selected fruits and leafy vegetables in Minna Metropolis of Niger State, Nigeria. J. Animal Product. Adv. 3(1): 6-11.

Uga S, Hoa N, Noda S, Moji K, Cong L, Aoki Y (2009). Parasite egg contamination of vegetables from a suburban market in Hanoi, Vietnam. Nepal. Med. Coll. J. 11(2): 75-78.

ul-Haq S, Maqbool A, Javed KU, Yasmin G, Sultana R (2014). Parasitic contamination of vegetables eaten raw in Lahore, Pakistan. J. Zool. 46(5): 1303-1309.

Uneke CJ (2004). Potential for geohelminth prasite transmission by raw fruits and vegetables in Nigeria: Implication for a risk profile. J. Nutr. Environ. Med.16 (1): 59-68.

Vadlamudi RS, Chi DS, Krishnaswamy G (2006). Intestinal strongyloidiasis and hyperinfection syndrome. Clin. Mol. Allergy 4(8).

Viney ME, Lok JB (2007). Strongyloides spp. Wormbook 23(2): 1-15. 